\title{
Genetic Polymorphism of Transforming Growth Factor $\beta 1$ and Tumor Necrosis Factor $\alpha$ Is Associated With Asthma and Modulates the Severity of Asthma
}

\author{
Chi-Huei Chiang MD, Chiao-Hui Chuang MSc, Shiou-Ling Liu MSc, and Horng-Der Shen PhD
}

\begin{abstract}
BACKGROUND: The role of transforming growth factor $\beta 1$ (TGF- $\beta 1$ ) and tumor necrosis factor $\alpha$ (TNF- $\alpha$ ) in asthma is unclear. The aim of this study was to assess the relationships among polymorphisms, clinical phenotypes, and the serum levels of TGF- $\beta 1$ and TNF- $\alpha$. METHODS: Polymorphisms of promoter of TGF- $\beta 1$ (C-509T locus) and TNF- $\alpha$ (G-308 A locus; rs 1800629) in 217 asthmatic patients and 110 healthy controls were evaluated. Pulmonary function, total immunoglobulin E (IgE), specific IgE antibodies, total eosinophil counts, TGF- $\beta 1$, and TNF- $\alpha$ were assessed. RESULTS: The genetic polymorphisms of TGF- $\beta 1$ promoter and TNF- $\alpha$ were significantly associated with asthma. Subjects with more severe asthma had higher serum levels of TGF- $\beta 1$ and TNF- $\alpha$. In asthmatic subjects the TGF- $\beta 1$ of atopic subjects was higher than those without atopy. All studied subjects (asthma plus control) were divided into 4 groups by mean value of TGF- $\beta 1$ or TNF- $\alpha$. The high values of TGF- $\beta 1$ or TNF- $\alpha$ were defined by higher than the mean values of the studied subjects of TGF- $\beta 1(392.42 \mathrm{pg} / \mathrm{mL})$ and TNF- $\alpha(55.86 \mathrm{pg} / \mathrm{mL})$. The FEV $\mathrm{V}_{1}$ of the group with high TGF- $\beta 1$ plus low TNF- $\alpha$ was lower than that in the group with low TGF- $\beta 1$ plus low TNF- $\alpha$. The lowest FEV 1 was in the group with high TNF- $\alpha$ and high TGF- $\beta 1$. CONCLUSIONS: The genetic polymorphisms of TGF- $\beta 1$ and TNF- $\alpha$ are associated with asthma. TGF- $\beta 1$ modulates atopy. Both TGF- $\beta 1$ and TNF- $\alpha$ modulate clinical severity and airway obstruction, in an additive manner. Key words: asthma; transforming growth factor $\beta 1$; tumor necrosis factor; phenotype. [Respir Care 2013;58(8):1343-1350. (C) 2013 Daedalus Enterprises]
\end{abstract}

\section{Introduction}

Asthma is a chronic inflammatory and remodeling disorder of the airways, in which many cells, cellular elements, and cytokines play important roles. Many cyto-

\footnotetext{
The authors are affiliated with the Division of Pulmonary Immunology and Infectious Diseases, Chest Department, with the exception of Dr Shen, who is affiliated with the Department of Medical Research and Education, Taipei Veterans General Hospital, Taipei, Taiwan. Dr Chiang is also affiliated with the Institute of Emergency and Critical Care Medicine, School of Medicine, National Yang-Ming University; the Medical School, National Defense Medical Center, and the Taipei Veterans General Hospital, Taipei, Taiwan.
}

This research was partly supported by grants V98C1-015, V99C1-111, V100-C-044, V101C-030 and V100D-007-1 from Taipei Veterans General Hospital, and grants NSC 97-2314-B-075-045NSC, 98-2314-B-075 -036 and NSC99-2314-B-075-034-MY2 from the National Science Council of Taiwan, and by the Division of Experimental Surgery, Department of Surgery, Pathology, and Statistics, Taipei Veterans General Hospital, Taiwan. The authors have disclosed no conflicts of interest. kines released by $\mathrm{T}$ cells, innate, and structural cells contribute to the different pathogenetic features of asthma. ${ }^{1,2}$

The severity of asthma is difficult to assess clinically. Asthma severity has traditionally been addressed using pulmonary function data to assess the airway obstruction, but cannot reflect the underlying asthma severity in stable clinical condition. Additionally, clinical symptoms are very subjective. $^{3}$ Identifying useful biomarkers that correlate

\footnotetext{
Supplementary material related to this paper is available at http:// www.rcjournal.com.

Correspondence: Chi-Huei Chiang MD, Division of Pulmonary Immunology and Infectious Diseases, Chest Department, Taipei Veterans General Hospital, No. 201, Section 2, Shih-Pai Road, Taipei, Taiwan. E-mail: chiang1990@gmail.com or chiang01@vghtpe.gov.tw.
}

DOI: $10.4187 /$ respcare. 02187 
with clinical symptoms and airway obstruction would be a very important addition to clinical staging of stable asthma. Stable asthmatic patients still have chronic inflammation and remodeling in the airways, ${ }^{4,5}$ which induces small airway obstruction. ${ }^{6}$ Therefore, identification of biomarkers of inflammation and remodeling in asthma may be relevant for assessment of severity of asthma.

Transforming growth factor $\beta 1$ (TGF- $\beta 1$ ) is one of the main mediators involved in tissue remodeling in the asthmatic lung. This profibrotic cytokine is produced by a number of cells, including macrophages, epithelial cells, fibroblasts, and eosinophils. High expression of TGF- $\beta 1$ in patients with asthma has been reported by many investigators. However, controversy remains whether the concentration of TGF- $\beta 1$ correlates with disease severity. TGF- $\beta 1$ is believed to play an important role in most of the cellular biological processes leading to airway remodeling. It was shown to be involved in epithelial changes, subepithelial fibrosis, airway smooth muscle remodeling, and microvascular changes. ${ }^{7,8}$

Tumor necrosis factor $\alpha(\mathrm{TNF}-\alpha)$ has been shown to be a highly pro-inflammatory cytokine in asthma, as it upregulates adhesion molecules, increases mucin secretion, and promotes airway remodeling. TNF- $\alpha$ is produced by a large number of cells in the airways, including mast cells, smooth muscle cells, epithelial cells, monocytes, and macrophages. This cytokine has been shown to be relevant, being increased in patients with severe asthma.9,10

To date, association between asthma and genetic polymorphisms of TGF- $\beta 1$ or TNF- $\alpha$ remains uncertain. Furthermore, serum concentration of TGF- $\beta 1$ or TNF- $\alpha$ in asthma has not been adequately explored to assess correlations with clinical phenotypes. We studied whether the genetic polymorphisms of TGF- $\beta 1$ or TNF- $\alpha$ are associated with asthma in Taiwan. Furthermore, we investigated whether serum concentration of TGF- $\beta 1$ or TNF- $\alpha$ is associated with asthmatic severity, airway obstruction, or atopy, and whether there is additive effect on modulation of asthma by combination of both TGF- $\beta 1$ and TNF- $\alpha$.

\section{QUICK LOOK}

\section{Current knowledge}

Genetic polymorphisms have been implicated in the pathogenesis of asthma. The roles of transforming growth factor $\beta 1$ (TGF- $\beta 1$ ) and tumor necrosis factor $\alpha$ $(\mathrm{TNF}-\alpha)$ in asthma are unclear

\section{What this paper contributes to our knowledge}

Gene polymorphisms of TGF- $\beta 1$ and TNF- $\alpha$ were associated with asthma. TGF- $\beta 1$ modulated atopy. Both TGF- $\beta 1$ and TNF- $\alpha$ modulated clinical severity and airway obstruction, in an additive manner.

\section{Methods}

The hospital review board for human studies approved the study protocol. Informed consent from each subject was obtained before participation. There is no conflict of interest for all authors.

\section{Study Subjects}

A cohort of 217 stable asthmatic subjects, who were diagnosed and followed up in the out-patient department of Taipei Veterans General Hospital, and 110 control subjects, who were healthy with no history of asthma or atopy, were recruited for this study (Table 1). To be eligible for inclusion, asthmatic subjects had to be clinically stable and cooperative to follow-up in the out-patient clinic. Exclusion criteria were: severe comorbidities such as organ failure, cancer, infection, autoimmune disease, or other conditions that can affect serum TGF- $\beta 1$ and $\mathrm{TNF}-\alpha$; and use of systemic steroids, oral anti-inflammatories, or other drugs that can affect these cytokines.

Asthmatic patients had to have all of the following characteristics, defined by the guideline of the Global Initiative for Asthma ${ }^{3}$ : at least 2 symptoms consistent with asthma

Table 1. Clinical Characteristics in Normals and Asthmatic Subjects

\begin{tabular}{|c|c|c|c|c|c|c|}
\hline & $\begin{array}{c}\text { Normal } \\
n=110\end{array}$ & $\begin{array}{l}\text { Intermittent } \\
\text { Asthma } \\
n=74\end{array}$ & $\begin{array}{c}\text { Mild } \\
\text { Asthma } \\
n=48\end{array}$ & $\begin{array}{c}\text { Moderate } \\
\text { Asthma } \\
n=38\end{array}$ & $\begin{array}{l}\text { Severe } \\
\text { Asthma } \\
n=57\end{array}$ & $P$ \\
\hline Male, no. (\%) & $46(41.82)$ & $35(47.30)$ & $26(54.17)$ & $21(55.26)$ & $27(47.37)$ & \\
\hline Female, no. $(\%)$ & $64(58.18)$ & $39(52.70)$ & $22(45.83)$ & $17(44.74)$ & $30(52.63)$ & \\
\hline Non-smokers, no. (\%) & $110(100)$ & $53(71.62)$ & $31(64.58)$ & $22(57.89)$ & $40(70.18)$ & \\
\hline Smokers, no. (\%) & $0(0)$ & $21(28.38)$ & $17(35.42)$ & $16(42.11)$ & $17(29.82)$ & \\
\hline Age, mean $\pm \mathrm{SD}$ y & $32.41 \pm 12.28$ & $61.98 \pm 17.25$ & $56.93 \pm 20.57$ & $54.03 \pm 15.59$ & $48.66 \pm 20.71$ & $<.001$ \\
\hline $\mathrm{FEV}_{1} \%$ predicted, mean $\pm \mathrm{SD} \%$ & $96.59 \pm 13.05$ & $80.97 \pm 15.23$ & $80.88 \pm 18.81$ & $78.12 \pm 19.08$ & $76.57 \pm 19.67$ & $<.001$ \\
\hline $\mathrm{FEV}_{1} / \mathrm{FVC}$, mean $\pm \mathrm{SD} \%$ & $90.81 \pm 10.47$ & $89.91 \pm 10.73$ & $73.93 \pm 16.15$ & $72.91 \pm 13.93$ & $69.49 \pm 12.54$ & $<.001$ \\
\hline
\end{tabular}


(cough, wheeze and dyspnea); either a positive bronchial hyper-responsiveness or a positive bronchodilator test, defined as $\mathrm{a} \geq 15 \%$ increase in baseline $\mathrm{FEV}_{1}$ after bronchodilator; and absence of other pulmonary disorders. Pulmonary function tests, inhaled bronchodilator response, and methacholine bronchial provocation tests were performed to confirm airway obstruction, obstruction reversibility, and airway hyper-reactivity, respectively. Pulmonary function (Automated Body Plethysmograph 6200 Autobox DL, SensorMedics, Yorba Linda, California) was assessed according to the guidelines of the American Thoracic Society. ${ }^{11}$ Airway hyper-responsiveness was measured by bronchial challenge with methacholine. ${ }^{12}$

Atopic phenotype was assessed based on total eosinophil count, total IgE, specific IgE, and total eosinophil count. Total IgE and specific IgE were measured from blood samples obtained from the asthmatic subjects. ${ }^{12}$ In asthmatic subjects we assessed total IgE and IgE specific for a number of common inhaled allergens in Taiwan, namely, Dermatophagoides pteronyssinus, Dermatophagoides farinae, Dermatophagoides microceras, cockroach, cat dander, and dog dander, by immuno-enzymatic fluorescence assay (IgE-FEIA and RAST-FEIA, Pharmacia CAP, Uppsala, Sweden). The results are expressed as KU/L, according to the manufacturer's instructions. All the latter assays were performed at the same time and analyzed by the same laboratory, according to a technique previously reported in detail. ${ }^{12}$ Total eosinophil count and $\mathrm{IgE}$ were measured in the enrolled asthmatic subjects.

\section{Genotyping}

DNA was extracted from blood samples with either a commercial kit (QIAamp Blood Kit, Qiagen, Chatsworth, California) or an automated nucleic acid purification system (Genepure, Applied Biosystems, Foster City, California).

\section{Promoter of TGF- $\beta 1$ (rs 1800469)}

C-509T genotyping was performed by restriction fragment length polymorphism analysis, as described in detail in the online data supplement (see the supplementary materials at http://www.rcjournal.com). An amplification of $406 \mathrm{bp}$ was generated by 35 cycles of polymerase chain reaction (PCR), using sense primer 5'-CCGCTTCTGTCCTTTCTAGG and antisense primer 5 '-AAAGCGGGTGATCCAGATG. PCR was performed in a total volume of $25 \mu \mathrm{L}$, with $50 \mathrm{pmol}$ of genomic DNA, $1 \mathrm{U}$ Taq polymerase (Promega, Madison, Wisconsin), 1X PCR buffer (Promega, Madison, Wisconsin), $1.5 \mathrm{mM} \mathrm{Mg} 2^{+}, 1 \mu \mathrm{M}$ primers, and $200 \mu \mathrm{M}$ dNTPs, with an annealing temperature of $60^{\circ} \mathrm{C}$. After PCR, $10 \mu \mathrm{L}$ of the reaction mixture was digested with $1 \mathrm{U}$ Eco81I (SauI) (Amersham Biosciences, Piscataway, New Jersey) in $1 \mathrm{X}$ buffer M (Amer- sham Biosciences, Piscataway, New Jersey) for 3 hours, at $37^{\circ} \mathrm{C}$. The digest mixture was resolved on a $1.5 \%$ agarose gel stained with ethidium bromide. DNA from individuals with the homozygous $\mathrm{C}$ genotype (CC) produced 2 bands: one at $223 \mathrm{bp}$ and one at $183 \mathrm{bp}$. The homozygous $\mathrm{T}$ genotype (TT) produced one band at $406 \mathrm{bp}$. The heterozygous genotype (CT) produced all 3 bands. ${ }^{13}$

\section{Promoter of Tumor Necrosis- $\alpha$ (TNF- $\alpha 308$ G/A, rs 1800629)}

Tumor necrosis- $\alpha$ G308A polymorphism was analyzed by PCR combined with restriction fragment length polymorphism. Fragments were amplified in $15 \mu \mathrm{L}$. The utilized primer, restriction enzyme, and expect products are as follows. The primers were 5'-AGG CAA TAG GTT TTG AGG GCC AT-3' and 5'-TCC TCC CTG CTC CGA TTC CG-3', and the restriction enzyme was NcoI (New England BioLabs, Beverly, Massachusetts). The $-308 \mathrm{G}$ allele yielded a single $107 \mathrm{bp}$ fragment, and the $-308 \mathrm{~A}$ allele yielded $87 \mathrm{bp}$ and $20 \mathrm{bp}$ fragments. ${ }^{14}$

Control DNA samples representative of each of the 3 genotypes were included on every agarose gel. Repeat genotyping was performed on 5 of every 100 samples chosen by random selection. Genotyping errors are estimated to have occurred at a frequency of $<1 \%$. Inconsistencies were resolved by 3 or more genotyping reactions.

\section{Blood Sampling and Analysis of Serum Content of TGF- $\beta 1$ and TNF- $\alpha$}

Blood samples were taken from the antecubital vein, between 7:00 $\mathrm{AM}$ and 8:00 $\mathrm{AM}$, after an overnight fast. Blood was processed within 1 hour of collection, and serum was aliquoted and stored at $-70^{\circ} \mathrm{C}$ until analysis. The levels of TGF- $\beta 1$ and TNF- $\alpha$ in serum were assayed by a standardized sandwich enzyme-linked immunosorbent assay (ELISA) method (Invitrogen, Camarillo, California). The absorbance was read at $450 \mathrm{~nm}$ (SpectraMax M5, Molecular Devices, Sunnyvale, California).

\section{Statistical Analysis}

The values for $\mathrm{FEV}_{1} \%$, total IgE, and total eosinophil are expressed as mean $\pm \mathrm{SD}$. The frequency genotypes are expressed as number and percentage. A test to show whether the studied populations were in Hardy-Weinberg equilibrium was carried out. The correlation between TGF- $\beta 1$ or TNF- $\alpha$ promoter polymorphism and asthma or its phenotypes was examined by the Fisher exact test, chi-square test, or Pearson chi-square test. Analysis of variance was used to compare the values for $\mathrm{FEV}_{1} \%$, total IgE, and total eosinophil count across the 3 genotypes or the serum level 
Table 2. Association of Asthma With Polymorphisms of TGF- $\beta 1$ and TNF- $\alpha$

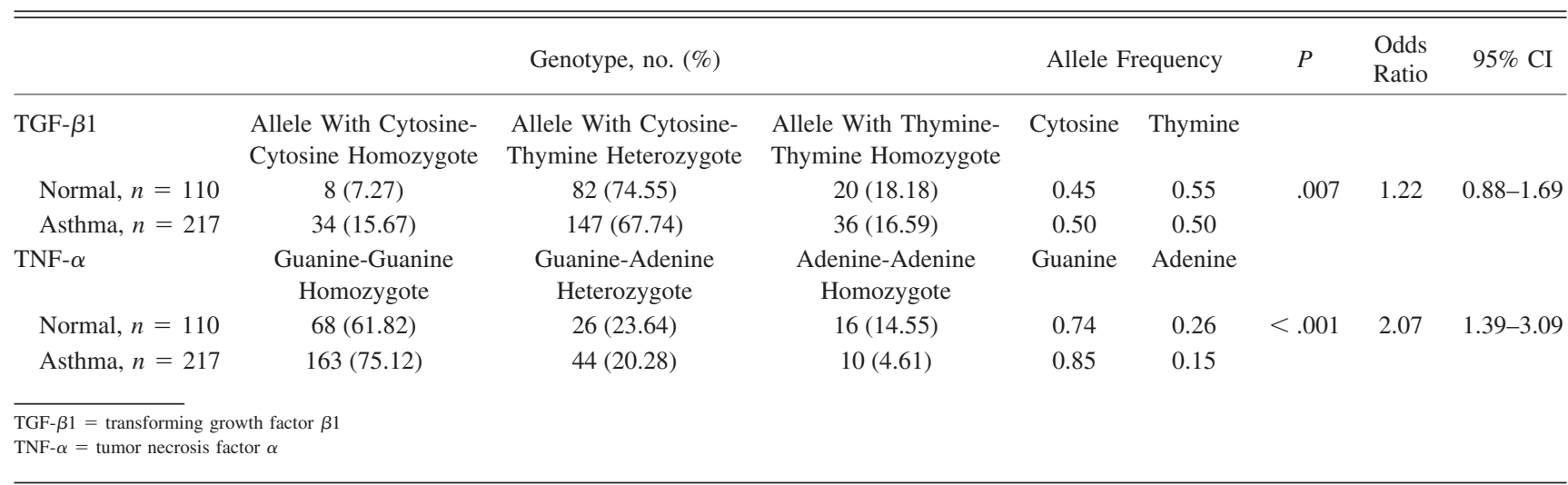
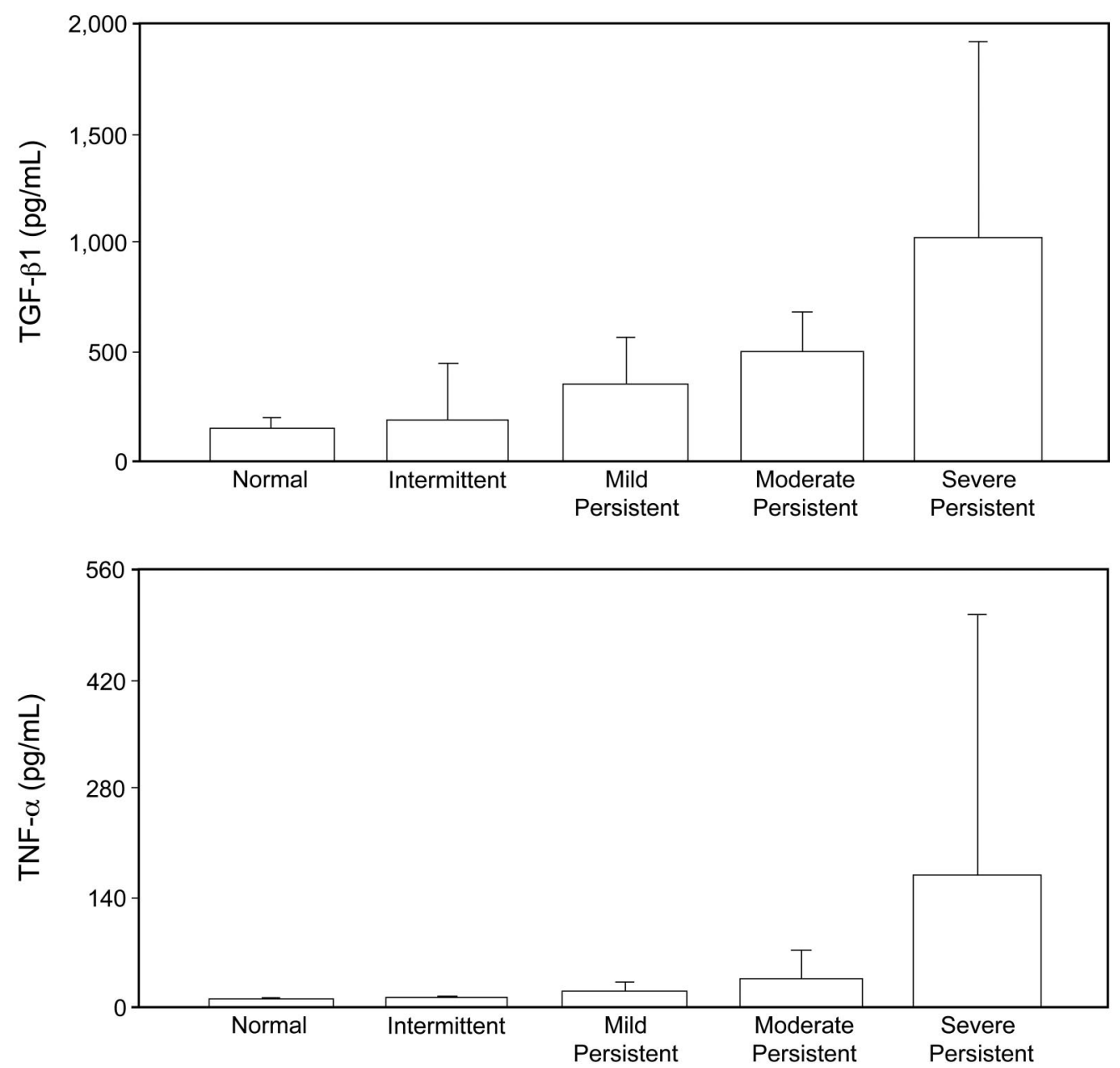

Fig. 1. Serum transforming growth factor $\beta 1$ (TGF- $\beta 1$ ) and tumor necrosis factor $\alpha$ (TNF- $\alpha$ ) in normal controls and subjects with asthma. For TGF- $\beta 1$ : normal versus mild persistent $P .001$; normal versus moderate persistent $P .001$; normal versus severe persistent $P .001$; intermittent versus mild persistent $P .009$; intermittent versus moderate persistent $P .001$; intermittent versus severe persistent $P .001$; mild persistent versus moderate persistent $P$.002; mild persistent versus severe persistent $P .001$; moderate persistent versus severe persistent $P$.001. For TGF- $\beta 1$ : normal versus intermittent $P .02$; normal versus mild persistent $P .001$; normal versus moderate persistent $P .001$; normal versus severe persistent $P .001$; intermittent versus mild persistent $P .001$; intermittent versus moderate persistent $P .001$; intermittent versus severe persistent $P .001$; mild persistent versus moderate persistent $P .01$; mild persistent versus severe persistent $P$.01; moderate persistent versus severe persistent $P .047$. 
Table 3. TGF- $\beta 1$, TNF- $\alpha, \mathrm{FEV}_{1}$, and FVC in Normals, Atopic Subjects, and Non-atopic Asthmatic Subjects

\begin{tabular}{|c|c|c|c|c|}
\hline & \multirow[b]{2}{*}{$\begin{array}{c}\text { Normal } \\
n=110\end{array}$} & \multicolumn{3}{|c|}{ Asthma $(n=217)$} \\
\hline & & $\begin{array}{c}\text { Allergy }+ \\
\text { Non-allergy }\end{array}$ & $\begin{array}{c}\text { Allergy } \\
n=113\end{array}$ & $\begin{array}{c}\text { Non-allergy } \\
n=104\end{array}$ \\
\hline TGF- $\beta 1, p g / m L$ & $146.20 \pm 54.91$ & $470.35 \pm 617.81 *$ & $611.30 \pm 769.11 * \dagger$ & $343.71 \pm 380.63 * \ddagger$ \\
\hline $\mathrm{TNF}-\alpha, \mathrm{pg} / \mathrm{mL}$ & $12.90 \pm 4.63$ & $70.83 \pm 204.00 *$ & $84.01 \pm 220.30 *$ & $58.49 \pm 187.54 *$ \\
\hline $\mathrm{FEV}_{1} \%$ predicted & $96.59 \pm 13.05$ & $78.57 \pm 18.33^{*}$ & $79.61 \pm 20.09^{*}$ & $77.71 \pm 15.58^{*}$ \\
\hline FVC \% predicted & $90.81 \pm 10.47$ & $87.52 \pm 16.38^{*}$ & $89.13 \pm 16.92^{*}$ & $85.55 \pm 15.60^{*}$ \\
\hline \multicolumn{5}{|c|}{ 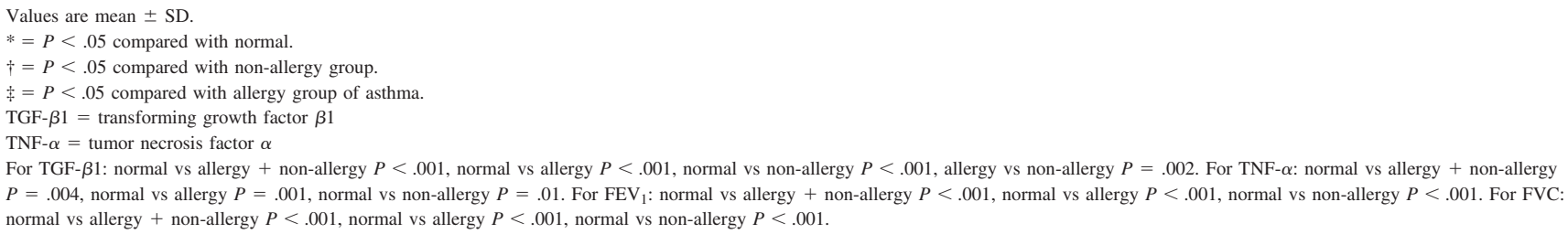 } \\
\hline
\end{tabular}

of TGF- $\beta 1$ or TNF- $\alpha$ in various severity or phenotypes of asthmatic subjects.

\section{Results}

\section{Testing for Hardy-Weinberg Equilibrium}

Our studied populations for subjects with asthma and controls showed an excellent fit to Hardy-Weinberg equilibrium.

\section{Association Between TGF- $\beta 1$ or TNF- $\alpha$ and Asthma}

The C-509T TGF- $\beta 1$ gene promoter polymorphism with $\mathrm{C}$ allele and TNF- $\alpha 238 \mathrm{G} / \mathrm{A}$ polymorphism with $\mathrm{G}$ allele of the asthmatic subjects were higher than the control subjects (Table 2).

\section{Genotypes of the TGF- $\beta 1$ Gene Promoter or TNF- $\alpha$ in Asthmatic Subjects With Various Allergy and Non-allergy Phenotypes}

We compared 2 different phenotypes in asthmatic subjects with allergy or non-allergy to mite, cockroach, dog dander, and cat dander, and found no significant differences in frequencies of TGF- $\beta 1$ or TNF- $\alpha$ gene promoters. In addition, the asthmatic subjects showed no significant difference in the frequencies of TGF- $\beta 1$ or TNF- $\alpha$ promoter gene polymorphisms with respect to normal or higher total IgE, normal or higher eosinophil counts, and normal or lower values of $\mathrm{FEV}_{1}$.

\section{Serum Levels of TGF- $\beta 1$ and TNF- $\alpha$ in Different Severities of Asthma}

The serum levels of TGF- $\beta 1$ and TNF- $\alpha$ were significantly different among asthma subjects with different dis- ease severities (intermittent, mild, moderate, and severe persistent asthma). Furthermore, TNF- $\alpha$ in subjects with intermittent asthma was higher than that in normals. These results suggest that TGF- $\beta 1$ and TNF- $\alpha$ may modulate the severity of clinical phenotypes; furthermore, TNF- $\alpha$ may be more sensitive then TGF- $\beta 1$ for assessing the early stage of asthma (Fig. 1).

\section{TGF- $\beta 1$, TNF- $\alpha$, FEV 1 , and FVC in Normal Controls and Atopic and Non-atopic Asthmatic Subjects}

The serum levels of TGF- $\beta 1$ and TNF- $\alpha$ in asthmatic subject with atopy or non-atopy was higher than those in normal controls (Table 3). Furthermore, the serum level of TGF- $\beta 1$ in asthmatic subjects with atopy was higher than that in asthmatic subjects with non-atopy. These results suggest that asthmatic subjects have higher TGF- $\beta 1$ and TNF- $\alpha$ in molecular phenotype, and that TGF- $\beta 1$ might modulate clinical atopic phenotype. In comparing asthmatic subjects with atopy and non-atopy, no significant difference of $\mathrm{FEV}_{1}$ was found.

\section{Interaction of Serum Levels of TGF- $\beta 1$ and TNF- $\alpha$}

The mean values of TGF- $\beta 1$ and TNF- $\alpha$ for all study subjects, including 110 normal controls and 217 asthmatic subjects, were $392.42 \mathrm{pg} / \mathrm{L}$ and $55.86 \mathrm{pg} / \mathrm{L}$, respectively. We defined the high or low levels based on these mean values. Four groups were assigned as follows: low TNF- $\alpha$ and low TGF- $\beta 1$; low TNF- $\alpha$ and high TGF- $\beta 1$; high TNF- $\alpha$ and low TGF- $\beta 1$; high TNF- $\alpha$ and high TGF- $\beta 1$. 

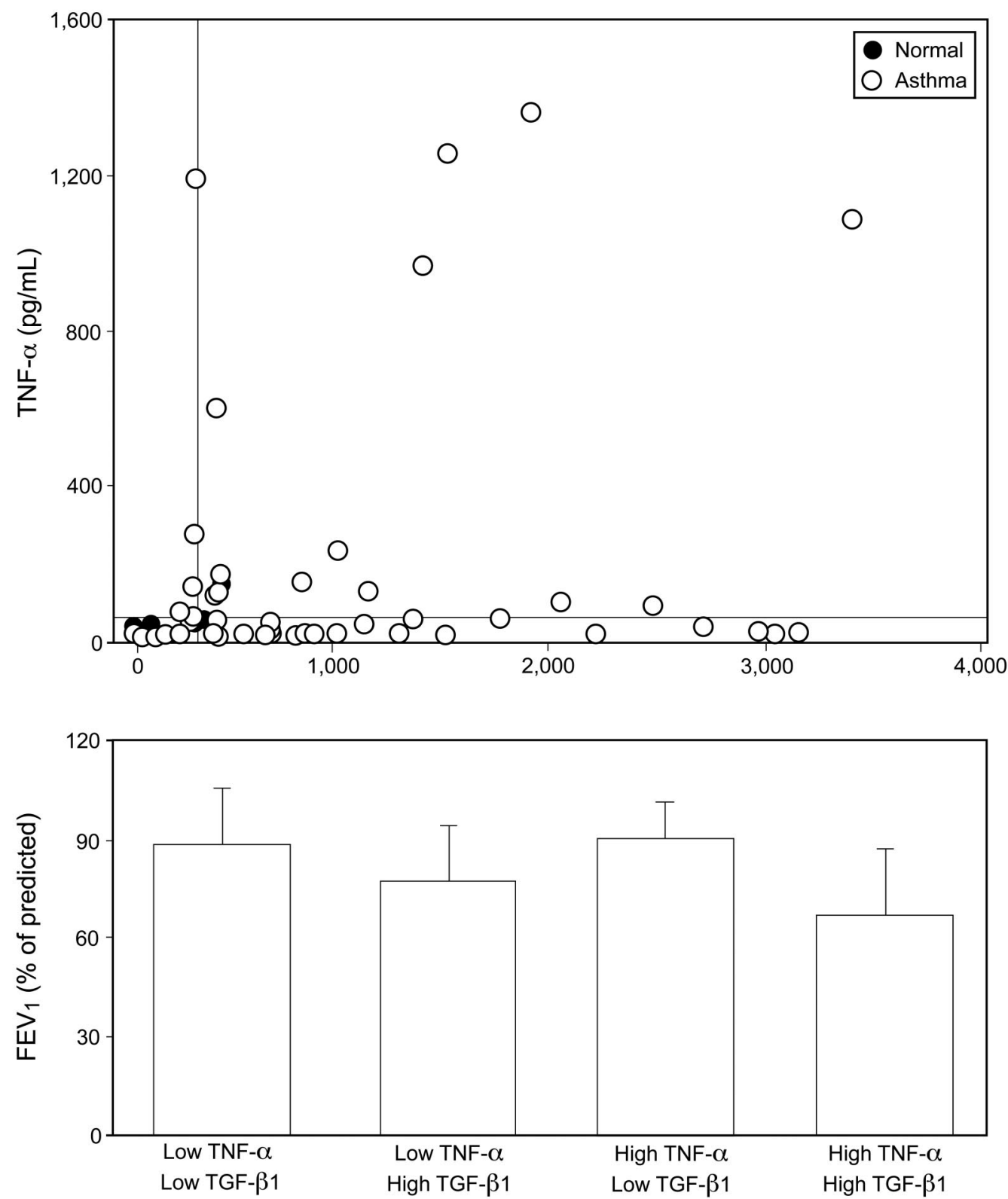

Fig. 2. Serum transforming growth factor $\beta 1$ (TGF- $\beta 1$ ) versus tumor necrosis factor $\alpha$ (TNF- $\alpha$ ) in normal controls and subjects with asthma. The 4 groups of studied subjects were divided into 4 groups by mean values of TNF- $\alpha$ and TGF- $\beta 1$ (A), then the FEV 1 values of the 4 groups were compared (B). A: Low TNF- $\alpha(<55.86 \mathrm{pg} / \mathrm{mL})$ and low TGF- $\beta 1(<392.42 \mathrm{pg} / \mathrm{mL})($ asthma 98, normal 110$)$. Low TNF- $\alpha(<55.86 \mathrm{pg} / \mathrm{mL})$ and high TGF- $\beta 1$ ( $>392.42 \mathrm{pg} / \mathrm{mL}$ ) (asthma 65, normal 0). High TNF- $\alpha(>55.86 \mathrm{pg} / \mathrm{mL}$ ) and low TGF- $\beta 1(<392.42 \mathrm{pg} / \mathrm{mL})(\mathrm{asthma} 19$, normal 0). High TNF- $\alpha$ (>55.86 pg/mL) and high TGF- $\beta 1$ (> $392.42 \mathrm{pg} / \mathrm{mL}$ ) (asthma 35, normal 0). B: The FEV ${ }_{1}$ of the group with low TNF- $\alpha$

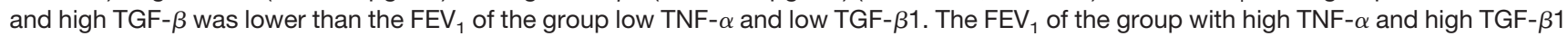
was lower than all the other groups. Low TNF- $\alpha$ and low TGF- $\beta 1$ versus low TNF- $\alpha$ and high TGF- $\beta 1 P$.001. Low TNF- $\alpha$ and low TGF- $\beta 1$ versus high TNF- $\alpha$ and high TGF- $\beta 1 P .001$. Low TNF- $\alpha$ and high TGF- $\beta 1$ versus high TNF- $\alpha$ and high TGF- $\beta 1 P .02$. High TNF- $\alpha$ and low TGF- $\beta 1$ versus high TNF- $\alpha$ and high TGF- $\beta 1 P .02$.

The FEV 1 of the low TNF- $\alpha$ and high TGF- $\beta 1$ group was lower than that of the low TNF- $\alpha$ and low TGF- $\beta 1$ group. The $\mathrm{FEV}_{1}$ of the high TNF- $\alpha$ and high TGF- $\beta 1$ group was lower than that of the other 3 groups (Fig. 2). These results indicate high TGF- $\beta 1$ and TNF- $\alpha$ have additive effect on reducing $\mathrm{FEV}_{1}$.

\section{Discussion}

Our study found polymorphisms of TGF- $\beta 1$ and TNF- $\alpha$ to be associated with asthma. The more severe clinical phenotype or airway obstruction in the asthmatic subjects was associated with higher serum TGF- $\beta 1$ or TNF- $\alpha$. 
Asthmatic subjects with atopy had higher TGF- $\beta 1$ levels than asthmatic subjects with non-atopy. TNF- $\alpha$ appeared to be more sensitive than TGF- $\beta 1$ for staging of early stable asthma. The combination of TGF- $\beta 1$ and TNF- $\alpha$ may have additive modulation on the degree of airway obstruction.

Results from previous studies of TGF- $\beta 1$ and TNF- $\alpha$ polymorphisms in asthma have been conflicting. Our finding showed polymorphisms of the TGF- $\beta 1$ gene promoter to be associated with asthma, as shown in a previous study. ${ }^{15-21}$ In a subgroup analysis by ethnicity, the risk of asthma associated with the $-509 \mathrm{~T}$ allele was significantly elevated among Asians but not among whites. ${ }^{21}$

TNF- $\alpha$ is a pro-inflammatory cytokine that is found in elevated concentrations in sputum, bronchoalveolar lavage, and lung biopsy samples from asthmatic patients. ${ }^{22}$ It plays a central role in the initiation of airway inflammation and the generation of airway hyper-reactivity. ${ }^{23}$ The TNF- $\alpha$ gene is a member of the TNF superfamily located on chromosome 6q21.24 Several polymorphisms have been identified in this gene, and the $-308 \mathrm{G} / \mathrm{A}$ polymorphism is one of the most studied $22-29$; however, the results were inconsistent. Our results show polymorphism in TNF- $\alpha$ gene to be associated with asthma. Our results support the recent meta-analysis showing the $-308 \mathrm{G} / \mathrm{A}$ polymorphism in TNF- $\alpha$ gene to be associated with asthma risk. ${ }^{30}$ In this meta-analysis study, subgroup analysis by ethnicity showed significant elevated risks for asthma to be associated with A allele carriers in Asians but not in whites. ${ }^{30}$ These conflicting results may have arisen from a range of factors, such as racial/ethnic differences, linkage or case-control association study, sample size, and the strictness of the asthmatic enrolment by definite diagnosis. Asthmatic subjects in the present study were strictly enrolled based on clear diagnostic criteria, and were regularly followed up in our out-patient clinic.

Our results support a previous study showing TGF- $\beta 1$ level in asthma to be higher than normal ${ }^{31,32}$; however, the previous study demonstrated only that there was a significant difference between serum TGF- $\beta 1$ in asthmatic subjects and control subjects. ${ }^{31,32}$ Furthermore, our results are the first to demonstrate that the higher level of TGF- $\beta 1$ is positively correlated with severity of clinical phenotypes in asthmatic subjects. TGF- $\beta 1$ mRNA was up-regulated in bronchial tissue from subjects with severe asthma ${ }^{32}$ and has been demonstrated to correlate with the thickness of subepithelial basement membrane. Thus, TGF- $\beta 1$ may contribute to the pathogenesis of airway remodeling in asthma. ${ }^{33}$

Asthma is characterized by the presence of an inflammatory cell infiltrate in the bronchial mucosa, consisting of activated mast cells, eosinophils, and T cells. Several cytokines are considered to play a pivotal role in this response, particularly interleukin (IL) 4, IL-5, IL-6, and
TNF- $\alpha$. Our results demonstrate for the first time the level of TNF- $\alpha$ to be significantly higher in severe clinical phenotypes of asthmatic subjects.

Asthma is a chronic inflammation and remodeling of airway disease. TNF- $\alpha$ contributes to the dysregulated inflammatory response seen in the asthmatic airway. TGF- $\beta 1$ is a main mediator involved in many aspects of persistent inflammation and tissue remodeling. Based on previous studies, both TGF- $\beta 1$ and TNF- $\alpha$ play key role in asthma pathogenesis of asthma. However, no previous research was found to investigate both cytokines' relationship in clinical phenotype and severities. We are the first to demonstrate that combined higher levels of both TGF- $\beta 1$ and TNF- $\alpha$ have additive effects on airway obstruction, as assessed by $\mathrm{FEV}_{1}$. Furthermore, we are first to demonstrate that serum TGF- $\beta 1$ in atopic asthmatic subjects is higher than in non-atopic asthmatic subjects. These results indicate TGF- $\beta 1$ to play an important role in atopy of clinical phenotypes in asthmatic subjects.

Limitations of this study include the small sample size, and the age of normal controls being younger than the other groups.

\section{Conclusions}

In conclusion, the polymorphisms of TGF- $\beta 1$ promoter gene and TNF- $\alpha$ gene are associated with asthma. TGF- $\beta 1$ and TNF- $\alpha$ modulate the severity of asthma, and TGF- $\beta 1$ is associated with atopy of asthmatic subjects. When combined, TGF- $\beta 1$ and TNF- $\alpha$ have additive effects on airway obstruction. Our results associating TGF- $\beta 1$ and TNF- $\alpha$ with clinical phenotypes of asthma suggest potential use of these parameters in the evaluation and management of asthma subjects, but the subject needs further investigations.

\section{ACKNOWLEDGMENTS}

We thank Jay Ryu MD, Department of Pulmonary and Critical Care Medicine, Mayo Clinic, Rochester, Minnesota, for editing the manuscript.

\section{REFERENCES}

1. Willart M, Hammad H Lung dendritic cell-epithelial cell crosstalk in Th2 responses to allergens Curr Opin Immunol 2011;23(6):772-777.

2. Barnes PJ. The cytokine network in asthma and chronic obstructive pulmonary disease. J Clin Invest 2008;118(11):3546-3556.

3. Global Initiative for Asthma (GINA). Guidelines for asthma management and prevention. Washington DC: National Institutes of Health; National Heart, Lung and Blood Institute; 2011.

4. Doherty GM, Kamath SV, de Courcey F, Christie SN, Chisakuta A, Lyons JD, et al. Children with stable asthma have reduced airway matrix metalloproteinase-9 and matrix metalloproteinase-9/tissue inhibitor of metalloproteinase-1 ratio. Clin Exp Allergy 2005;35(9): 1168-1174.

5. Fish JE, Peters SP. Airway remodeling and persistent airway obstruction in asthma. J Allergy Clin Immunol 1999;104(3 Pt 1):509-516. 
6. Chiang $\mathrm{CH}$, Hsu K. Residual abnormalities of pulmonary function in asymptomatic young adult asthmatics with childhood-onset asthma. J Asthma 1997;34(1):15-21.

7. Halwani R, Al-Muhsen S, Al-Jahdali H, Hamid Q. Role of transforming growth factor- $\beta$ in airway remodeling in asthma. Am J Respir Cell Mol Biol 2011;44(2):127-133.

8. Makinde T, Murphy RF, Agrawal DK. The regulatory role of TGFbeta in airway remodeling in asthma. Immunol Cell Biol 2007;85(5): 348-356.

9. Corren J. Cytokine inhibition in severe asthma: current knowledge and future directions. Curr Opin Pulm Med 2011;17(1):29-33.

10. Berry M, Brightling C, Ian Pavord I, AJ Wardlaw. TNF- $\alpha$ in asthma. Curr Opin Pharmacol 2007;7(3):279-228.

11. American Thoracic Society. Lung function testing: selection of reference values and interpretative strategies. Am Rev Respir Dis 1991; 144(5):1202-1218.

12. Chiang CH, Tang YC, Lin MW, Chung MY. Association between the IL-4 promoter polymorphisms and asthma or severity of hyperresponsiveness in Taiwanese. Respirology 2007;12(1):42-48.

13. Vignola AM, Chanez P, Chiappara G, Merendino A, Pace E, Rizzo A, et al. Transforming growth factor-beta expression in mucosal biopsies in asthma and chronic bronchitis. Am J Respir Crit Care Med 1997;156(2 Pt 1):591-599.

14. Kim HB, Kang MJ, Lee SY, Jin HS, Kim JH, Kim BS, et al. Combined effect of tumour necrosis factor-alpha and interleukin-13 polymorphisms on bronchial hyperresponsiveness in Korean children with asthma. Clin Exp Allergy 2008;38(5):774-780.

15. Silverman ES, Palmer LJ, Subramaniam V, Hallock A, Mathew $S$, Vallone $\mathrm{J}$ et al. Transforming growth factor-betal promoter polymorphism C-509T is associated with asthma. Am J Respir Crit Care Med 2004;169(2):214-219.

16. Salam MT, Gauderman WJ, McConnell R, Lin PC, Gilliland FD. Transforming growth factor- 1 C-509T polymorphism, oxidant stress, and early-onset childhood asthma. Am J Respir Crit Care Med 2007; 176(12):1192-1199.

17. Mak JC, Leung HC, Ho SP, Law BK, Ho AS, et al. Analysis of TGF-beta(1) gene polymorphisms in Hong Kong Chinese patients with asthma. J Allergy Clin Immunol 2006;117(1):92-96.

18. Kumar A, Gupta V, Changotra H, Sarin BC, Sehajpal PK. Tumor necrosis factor alpha and transforming growth factor beta1 polymorphisms in bronchial asthma. Indian J Med Sci 2008;62(8):323-330.

19. Ueda T, Niimi A, Matsumoto H, Takemura M, Yamaguchi MM, Matsuoka H, et al. TGFB1 promoter polymorphism C-509T and pathophysiology of asthma. J Allergy Clin Immunol 2008;121(3):659-664.

20. Lv J, Liu Q, Hua L, Dong X, Bao Y. Association of five single nucleotide polymorphism loci with asthma in children of Chinese Han nationality. J Asthma 2009;46(6):582-585.
21. Zhang Y, Zhang J, Huang J, Li X, He C, Tian C et al. Polymorphisms in the transforming growth factor-betal gene and the risk of asthma: a meta-analysis. Respirology 2010;15(4):643-650.

22. Sharma S, Sharma A, Kumar S, Sharma SK, Ghosh B. Association of TNF haplotypes with asthma, serum IgE levels, and correlation with serum TNF-alpha levels. Am J Respir Cell Mol Biol 2006; 35(4):488-495.

23. Li YF, Gauderman WJ, Avol E, Dubeau L, Gilliland FD. Associations of tumor necrosis factor G-308A with childhood asthma and wheezing. Am J Respir Crit Care Med 2006;173(9):970-976.

24. Noguchi E, Yokouchi Y, Shibasaki M, Inudou M, Nakahara S, Nogami $\mathrm{T}$, et al. Association between TNFA polymorphism and the development of asthma in the Japanese population. Am J Respir Crit Care Med 2002;166(1):43-46.

25. Mahdaviani SA, Rezaei N, Moradi B, Dorkhosh S, Amirzargar AA, Movahedi M. Proinflammatory cytokine gene polymorphisms among Iranian patients with asthma. J Clin Immunol 2009;29(1):57-62.

26. Wang JY, Liou YH, Wu YJ, Hsiao YH, Wu LS. An association study of 13 SNPs from seven candidate genes with pediatric asthma and a preliminary study for genetic testing by multiple variants in Taiwanese population. J Clin Immunol 2009;29(2):205-209.

27. Bilolikar H, Nam AR, Rosenthal M, Davies JC, Henderson DC, Balfour-Lynn IM. Tumour necrosis factor gene polymorphisms and childhood wheezing. Eur Respir J 2005;26(4):637-646.

28. Beghe B, Padoan M, Moss CT, Barton SJ, Holloway JW, Holgate ST, et al. Lack of association of HLA class I genes and TNF alpha -308 polymorphism in toluene diisocyanate-induced asthma. Allergy 2004;59(1):61-64.

29. El BL, Christensen M, Binaei S, Murphy C, Zhang Q, Quasney M. Lack of association between the tumor necrosis factor-alpha regulatory region genetic polymorphisms associated with elevated tumor necrosis factor-alpha levels and children with asthma. Chest 2003; 123(3 Suppl):374S-375S.

30. Zhang Y, Zhang J, Tian C, Xiao Y, He C, Li X et al. The -308 G/A polymorphism in TNF- $\alpha$ gene is associated with asthma risk: an update by meta-analysis. J Clin Immunol 2011;31(2):174-185.

31. Manuyakorn W, Kamchaisatian W, Atamasirikul K, Sasisakulporn C, Direkwattanachai C, Benjaponpitak S. Serum TGF-beta1 in atopic asthma. Asian Pac J Allergy Immunol 2008;26(4):185-189.

32. Ozyilmaz E, Canbakan S, Capan N, Erturk A, Gulhan M. Correlation of plasma transforming growth factor beta 1 with asthma control test. Allergy and Asthma Proceedings 2009;30(1):35-40.

33. Ohno I, Nitta Y, Yamauchi K, Hoshi H, Honma M, Woolley K, et al. Transforming growth factor beta 1 (TGF beta 1) gene expression by eosinophils in asthmatic airway inflammation. Am J Respir Cell Mol Biol 1996;15(3):404-409. 